Note

\title{
Prolactin and Bromocryptine Induced Changes in Liver, Adipose Tissue and Blood Lipids of Mature Male Bonnet Monkeys, Macaca radiata (Geoffroy)
}

\author{
M. Michael ARULDHAS, L. Thara THAMPI, \\ T. MeEnA Krishna KUMARI AND P. GOVINDARAJULU \\ Department of Endocrinology, Dr. A. L. M. Post Graduate \\ Institute of Basic Medical Sciences, University of Madras, \\ Madras-600 113, India
}

\begin{abstract}
Effects of prolactin and bromocryptine on neutral and phospholipids of liver, adipose tissue and serum were studied in mature male bonnet monkeys. Hyperprolactinemia (ovine prolactin, $250 \mu \mathrm{g} /$ $\mathrm{kg}$ body weight/day, i.p. for 30 days) elevated hepatic total lipids and phospholipids and decreased total and free cholesterol. While triacyl glycerol accumulated, mono-and diacyl glycerols diminished in liver and adipose tissues of prolactin treated monkeys. Concentrations of all phospholipid fractions, except sphingomyelin and cardiolipin in adipose tissue accrued in both tissues. Serum triacylglycerol, phosphatidyl ethanolamine, phosphatidyl choline and phosphatidyl inositol showed a significant increase in hyperprolactinaemic monkeys. Bromocryptine $(1 \mathrm{mg} / \mathrm{kg}$ body weight/day for 30 days) treatment reduced serum phospholipids without altering hepatic or adipose tissue lipids. The present study indicates that hyperprolactinaemia leads to hyperlipidemia due to accretion of hepatic and adipose tissue triacyl glycerol and certain phospholipid fractions. Bromocryptine has a specific inhibitory effect on serum phospholipids.
\end{abstract}

Key words: Adipose tissue, Bromocryptine, Cholesterol, Glycerides, Liver, Prolactin, Phospholipids, Serum, Lipids.

(Endocrine Journal 41: 207-212, 1994)

HYPERPROLACTINAEMIA is one of the major endocrine disorders, often associated with gonadal dysfunctions in men and women [1-4]. The physiological changes in reproductive and other endocrine organs in hyperprolactinaemia have been reviewed extensively [5-6]. Although prolactin is known to influence lipid metabolism in a number of vertebrates [7-10], the impact of hyperprolactinaemia on lipid metabolism, particularly in higher primates is not well understood.

Earlier, we reported the impact of hyperprolactinaemia on lung [11], testicular [12] and epididy-

Received: August 6, 1993

Accepted: December 14, 1993

Correspondence to: Dr. M. Michael ARULDHAS, Department of Endocrinology, Dr. A. L. M. Post Graduate Institute of Basic Medical Sciences, University of Madras, Taramani, Madras 600 113, India mal lipids [13] of monkeys. In the present paper, we report the impact of experimentally induced hyper-and hypoprolactinaemia on various classes of lipids in liver, adipose tissue, the important sites of lipid metabolisms [14], and in blood, to obtain a comprehensive idea of the impact of altered prolactin status on lipid metabolism in primates. The study was carried out in bonnet monkeys, a close animal (primate) model for simulation of human diseases.

\section{Materials and Methods}

\section{Chemicals}

Ovine prolactin for biological studies was a gift from the National Institute of Diabetes, Digestive 
and Kidney Diseases (NIDDK), National Hormone and Pituitary Program, Baltimore, Maryland, USA. Bromocriptine mesylate was a gift from Sandoz Pharmaceuticals, Switzerland. Polyvinyl pyrolidone (PVP) and lipid standards were from Sigma Chemical Company, USA. All other chemicals were of analytical grade and purchased from Glaxo and BDH (India). Radioimmunoassay kit for prolactin was from the World Health Organisation.

\section{Animals}

Mature male bonnet monkeys, Macaca radiata (Geoffroy) weighing 8-10 kg were housed in a well ventilated animal house with a $12 \mathrm{~h}$ dark and $12 \mathrm{~h}$ light schedule and provided with clean water and standard monkey pellet diet (Gold Mohur, Hindustan Lever Ltd., India) ad libitum. The monkeys were divided into three groups of 5 each.

Group I: Monkeys belonging to this group were given a single dose of $250 \mu \mathrm{g}$ ovine prolactin $/ \mathrm{kg}$ body weight/day, intraperitoneally, for 30 days to induce hyperprolactinaemia. 10\% PVP in saline was used as the vehicle as it enhances hepatic prolactin binding [15].

Group II: Bromocryptine mesylate, an ergot alkaloid which inhibits pituitary prolactin release through $\beta$ adrenergic receptors was injected at a dose of $1 \mathrm{mg} / \mathrm{kg}$ body weight/day, intraperitoneally, for 30 days to induce hypoprolactinaemia. Bromocryptine was dissolved in $0.9 \%$ alkaline saline.

Group III: This group served as control and was injected with $0.9 \%$ alkaline saline or PVP/day, for 30 days. As there was no appreciable difference between the lipid values obtained in the saline and PVP treated controls, a common control (PVP) was used for statistical analysis of data.

\section{Blood sampling}

Blood was drawn periodically from the femoral vein to assay prolactin in order to ascertain whether the animals had sustained hypo-and hyperprolactinaemia.

Serum prolactin, assessed on RIA double antibody technique with reagents supplied by the $\mathrm{WHO}$, rose from $329 \pm 62.4 \mathrm{mU} / \mathrm{l}$ in the control animals to $2640 \pm 107.9$ in the prolactin treated monkeys and fell to $26.4 \pm 1.90 \mathrm{mU} / l$ in the bromocryptine treated monkeys, confirming hyper- and hypoprolactinaemia, respectively.

Twenty-four hours after the last injection, the animals were fasted overnight, blood was drawn from the femoral vein, the serum separated and used for the estimation of lipids. After this, the animals were anaesthetized with sodium pentabarbitone $(30 \mathrm{mg} / \mathrm{kg}$ body wt.) and transcardially perfused with $0.9 \%$ saline till the liver was completely blanched.

Liver and adipose tissues were excised, cleared of adhering tissues and blood clots and stored at $-20^{\circ} \mathrm{C}$ till used subsequently for biochemical analysis. All assays were completed within 1-2 wks of sacrifice.

\section{Extraction and quantification of lipids}

Lipids were extracted from known amounts of serum, liver and adipose tissue in a mixture of chloroform: methanol ( $2: 1)$ [16], containing $0.01 \%$ butylated hydroxy toluene as an antioxidant was centrifuged thrice at $3000 \times \mathrm{g}$ for $10 \mathrm{~min}$, supernatants were concentrated in vacuo in a flash rotatory vacuum evaporator (Buchi, Switzerland) at 40 $45^{\circ} \mathrm{C}$ [16] and proteolipids were broken by repeating the above process. Total lipids were quantified with vanillin in a medium of sulphuric and phosphoric acids to form chromogen [17], and cholesterol quantification was based on Tachugaeff's color reaction [18]. Estimation of glyceride glycerol involved saponification of glycerides, oxidation of glycerol to formaldehyde and formic acid and estimation of the formaldehyde chromotrophic acid color complex [19]. Phospholipids [20] were estimated by following the reduction of phosphomolybdic acid with amino naphthosulphonic acid. Neutral and Phospholipid fractions were separated by thin layer chromatography on silica gel $G$ plates, using n-hexane: diethyl ether: glacial acetic acid [21] and chloroform: methanol: $7 \mathrm{~N}$ ammonia solvent systems [22], respectively.

The recovery percentages for the individual fractions of neutral and phospholipids were: Monoacyl glycerol $88 \%$, diacyl glycerol $93 \%$, triacyl glycerol $97 \%$, free cholesterol $97 \%$, esterified cholesterol $98 \%$, phosphatidyl inositol $96 \%$, phosphatidyl serine $96 \%$, phosphatidyl choline $95 \%$, phosphatidyl ethanolamine $97 \%$, phosphatidic acid $87 \%$, sphingomyelin $95 \%$ and cardiolipin $96 \%$. 


\section{Statistical analysis}

The data were statistically analysed by Student's $t$ test.

\section{Results}

Hyperprolactinaemia caused a significant increase in hepatic total lipids $(P<0.05)$ without altering the same in serum and adipose tissue. Even though total glyceride glycerol remained unaltered, mono-and diacyl glycerol concentrations decreased and triacyl glycerol increased in liver and adipose tissue due to prolactin treatment. Hyperprolactinaemia increased serum triacylglycerol also. Total and free cholesterol diminished in the liver alone. Bromocryptine treatment did not produce any significant change in neutral lipid classes of liver, adipose tissue and serum (Table 1).

Hepatic and adipose tissue phospholipids (total) and its fractions, accumulated in response to prolactin treatment except sphingomyelin and cardiolipin in adipose tissue. Serum phosphatidylcholine, phosphatidyl ethanolamine and phosphatidyl inositol also exhibited increases in hyperprolactinaemic monkeys. Bromocryptine induced hypoprolactinaemia decreased these phospholipids in serum. Even though, serum phosphatidyl serine was low in hypo- and hyperprolactinaemic monkeys, the bromocryptine induced decrease was more obvious than hyperprolactinaemia (Table 2).

\section{Discussion}

The data obtained in the present study demonstrate that chronic hyperprolactinaemia modifies the tissue and serum lipid pattern in primates. Hypertriglyceridemia and accumulation of phospholipids in liver, adipose tissue and serum seems to be a major effect of chronic hyperprolactinaemia. The observed hypertryglyceridemic effect in hyperprolactinaemic monkeys is therefore parallel to that reported in hyperprolactinaemic human subjects [23].

Short term prolactin treatment $(1 \mathrm{mg} / \mathrm{kg}$ body weight/day for 10 days) also revealed accumula- tion of hepatic glycerol stores and phospholipids in immature male monkeys [24]. The above study also showed enhanced activities of hepatic lipogenic enzymes like ATP citrate lyase, malic enzyme, malate dehydrogenase, glucose-6-phosphate dehydrogenase and 6-phosphogluconate dehydrogenase indicating a lipogenic effect of prolactin on primate liver. Additional evidence of a lipogenic effect of prolactin can also be obtained from studies on the mammary glands and monkey brain [25-27]. Nevertheless, one has to be cautious in arriving at such conclusions as reduced triacylglycerides is reported in the lungs [11], testes [12] and epididymis [13] of hyperprolactinaemic monkeys, suggesting an organ specific effect.

Unlike glycerides, the cholesterol pool is adversely affected in hyperprolactinaemic monkeys. The observed reduction in total and free cholesterol in the liver is similar to earlier reports on the testes [12] and lungs [11] of hyperprolactinaemic monkeys. This may point out a differential effect of hyperprolactinaemia on the two classes of neutral lipids. The present study also reveals the specific stimulatory influence of hyperprolactinaemia on hepatic, adipose tissue and serum phospholipid classes. Phospholipids and cholesterol play a vital role in membrane function and are essential modulators of membrane bound enzymes [28]. Therefore, the observed reduction in cholesterol and accumulation of phospholipids in liver and adipose tissue of hyperprolactinaemic monkeys is suggested to modify membrane permeability and related metabolic activities by altering the cholesterol: phospholipid ratio. Latha, [24] also reported enhanced hepatic phospholipids and its fractions in prolactin treated immature male bonnet monkeys. This effect of prolactin is specific to hepatic and adipose tissues and serum as major classes of phospholipids have remained unchanged in the lungs [11] testes, [12] and decreased in the epididymis [13] of hyperprolactinaemic monkeys.

Liver contains a high concentration of prolactin receptor $[29,30]$ and prolactin has a positive effect on its own receptor [31,32]. Therefore, the observed effect on neutral and phospholipids could be due to a direct effect of prolactin on liver. Nevertheless, the indirect effect mediated through insulin cannot be ruled out as prolactin acts like insulin in enhancing hepatic lipogenic enzyme activities although serum insulin titres were unaltered in hyperprolactinaemic monkeys [24, 33]. 

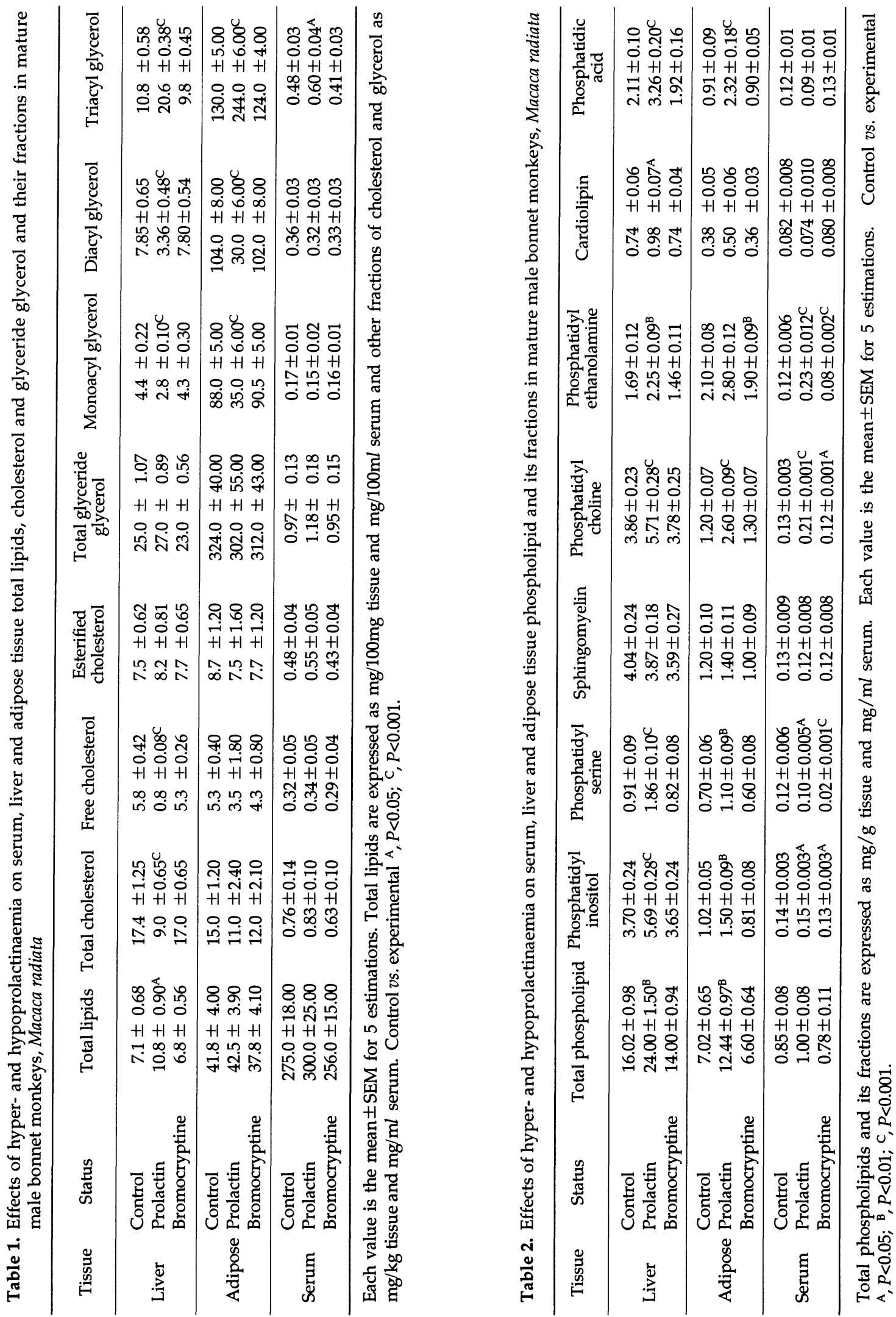
The data on neutral and phospholipid fractions suggest that hyperprolactinaemia favours the shunting of diacyl glycerol for the synthesis of triacyl glycerol and phospholipids as the diacyl glycerol concentration decreased in prolactin treated monkeys. It is well-established that diacyl glycerol serves as a precursor for triacyl glycerol, phosphatidyl choline and ethanolamine [14]. Despite an increased concentration of phosphatidyl serine in the liver and adipose tissues of hyperprolactinaemic monkeys, serum fractions decreased, possibly indicating interference with the release or uptake of this phospholipid class in the hyperprolactinaemic condition. The observed unchanged sphingomyelin in hyper - and hypoprolactinaemic conditions suggest that this phospholipid fraction is resistant to altered prolactin status. Further, in vitro studies on the role of prolactin on lipogenesis in isolated cell types may throw more light on this aspect.

The effect of bromocriptine is felt mainly on serum phospholipids such as phosphatidyl inositol, choline and ethanolamine, which is opposite to hyperprolactinaemia. This might be a direct effect of bromocryptine, specific to serum lipids, as hepatic and adipose tissue fractions were not altered. Additional supportive data on in vitro effects of bromocryptine on blood cells may clarify this.

The present study therefore, points out hypertriglyceridemia and accumulation of phospholipid stores in hyperprolactinaemic monkeys, leading to hyperlipidemia.

\section{Acknowledgements}

The authors acknowledge with thanks the kind gifts of ovine prolactin from NIADDK, Maryland, USA and bromocryptine mesylate from Sandoz, Sweden. We also thank Dr. P. G. Jayakumar for his assistance in conducting this study. One of the authors (TMKK) is grateful to the Council of Scientific and Industrial Research, New Delhi and another (LTT) to the University Grants Commission, New Delhi for the grants of a research fellowship, under the tenure of which the research programme was carried out.

\section{References}

1. Carter JN, Tyson JE, Tolis G, Van Vliet S, Faiman C, Friesen HG (1978) Prolactin secreting tumors and hypogonadism in 22 men. New Eng J Med 299: 847852.

2. Perryman RL, Thorner MO (1981) The effect of hyperprolactinaemia on sexual and reproductive function in men. J Androl 2: 233-242.

3. del Pozo E (1985) Management of borderline hyperprolactinaemia. Hormone Res 22: 204-208.

4. Soules MR, Bremmer WJ, Steiner RA, Clifton DK (1991) Prolactin secretion and corpus luteum formation in women with luteal phase deficiency. $J$ Clin Endocrinol Metab 72: 986-992.

5. Fluckiger E, del Pozo E, von Werder, K (1982) Prolactin: Physiology, pharmacology and clinical findings. In: Heidelberg FG, Grumbach MM, Zurich AZ (eds) Monographs on Endocrinology. Springer Verlag, New York, 23: 1-24.

6. Malarkey WB (1986) Effects of hyperprolactinaemia on other endocrine systems. In: Olefsky JM (ed) Contemporary issues in Endocrinology \& Metabolism 2: 21-41.

7. Goodridge AG, Ball EG (1967). The effect of prolactin on lipogenesis in the pigeon. Biochemistry 6: 2335-2343.
8. Meier AH (1975) Chronophysiology of prolactin in lower vertebrates. Am Zoologists 15: 905-916.

9. Meier AH, Burns JT (1976) Circadian hormone rhythms in lipid metabolism. Am Zoologists 16: 649-659.

10. Horseman ND, Meier AH (1979) Circadian phase dependent prolactin mechanism in hepatic lipogenesis of a teleosts. J Endocr 82: 367-372.

11. Antony FF, Govindarajulu P, Aruldhas MM (1991) Influence of prolactin on pulmonary lipids in mature male bonnet monkeys, Macaca radiata. Ind J Med Res 94: 370-374.

12. Aruldhas $M M$, Udhayakumar RCR, Sobbana $R$, Jayakumar PG, Govindarajulu P (1990) Impact of hyperprolactinaemia on testicular neutral lipids and phospholipids in mature bonnet monkeys, Macaca radiata. (Geoffroy) Ind J Exp Biol 28: 887-889.

13. Jayakumar PG (1989) Role of prolactin on epididymal glycoproteins and lipids of mature male bonnet monkeys, Macaca radiata (Geoffroy) Ph. D Thesis. University of Madras, India.

14. Mayes PA (1990) Metabolism of acylglycerols and sphingolipids. In: Murray RR, Granner DK, Mayes PA, Rodwell VW (eds) Harper's Biochemistry. 22nd edition, Appleton-Lange Publication, pp 226- 
233.

15. Manni A, Chambers MJ, Pearson OH (1978) Prolactin induces its own receptors in rat liver. Endocrinology 103: 2168-2171.

16. Folch J, Lees M, Sloane - Stanley GH (1957) A simple method for the isolation and purification of total lipids from animal tissues. J Biol Chem 226: 497-509.

17. Frings CS, Fendley TW, Dunn RT, Queen CA (1972) Improved determination of total serum lipid by the sulphophosphovanillin reaction. Clin Chem 18: 673-674.

18. Hanel HK, Dam H (1955) Determination of small amount of total cholesterol by the Tschugaeff reaction with a note on the determination of lathosterol. Acta Chem Scand 9: 677-682.

19. Van Handel E, Zilversmith DB (1957) Micromethod for the direct determination of serum triglycerides. J Lab Clin Med 50: 152-157.

20. Marinetti GV (1962) Chromotographic separation, identification \& analysis of phosphotides. J Lipid Res 3: 1-20.

21. Mangold HK (1965) Aliphatic lipids. In: Stahl E (ed) Thin Layer Chromotography. Academic Press, New York: 137-139.

22. Abramson D, Blecher H (1964) Quantitative 2 dimensional thin layer chromatography of naturally occurring phospholipids. J Lipid Res 5: 628-633.

23. Aisaka K (1982) Effects of prolactin on lipid metabolism. Nippon Sanka Fujinka Gakkai Zasshi 34: 559-568.

24. Latha K (1985) Influence of prolactin on lipids. Ph. D Thesis University of Madras, India.

25. Cameron CM, Linebaugh BE, Rillema JA (1983)
Hormonal control of lipid metabolism in mouse mammary gland explants. Endocrinology 112: 10071011.

26. Watters SB, Rillema JA (1988) Effect of prolactin on enzymes of lipid biosynthesis in mammary gland explants. Am J Physiol 255 (Endocrinol Metab 18) E567-E571.

27. Kumaran B (1986) Role of prolactin and bromocryptine on the neural and glial cellular metabolism in immature and mature male bonnet monkeys, Macaca radiata. $\mathrm{Ph} \mathrm{D}$ Thesis, University of Madras, India.

28. Gregoriadis G (1977) Possible implications in the use of exogenous phospholipids. Life Sci 20: 17731786.

29. Herrington AC, Stevenson J, Coulson L, Ymer S (1986) Characterization of a soluble prolactin binding activity in rat liver cytosol. J Endocr 109: 61-66.

30. Jolioceur C, Boutin JM, Okumura K, Raquet S, Djiane J, Kelly PA (1989) Multiple regulation of prolactin gene expression in rat liver. Mol Endocrinol 3: 895-900.

31. Posner BI, Kelly PA, Friesen HG (1975) Prolactin receptors in rat liver: Possible induction by prolactin. Science 188: 57-59.

32. Amit T, Barkey RJ, Gavish M, Youdim MBH (1984) Induction of prolactin receptors by $\mathrm{PRL}$ in the rat lung and liver. Demonstration and characterization of a soluble receptor. Endocrinology 114: 545-552.

33. Kumari TMK, Govindarajulu P (1990) The influence of hyperprolactinaemia on hepatic nucleic acids and few enzymes of intermediary metabolism. Med Sci Res 18: 701-703. 